\title{
Una teoría ficcional del poder. Historia, cuerpo y pregunta en El Señor Presidente de Miguel Ángel Asturias
}

\author{
Marcel Velázquez" \\ Universidad Nacional Mayor de San Marcos
}

\section{RESUMEN}

Este artículo discute los usos de la historia en la novela El Señor Presidente de Miguel Ángel Asturias y propone que esta es la primera novela latinoamericana que formaliza una elaborada teoría ficcional del poder, que se sustenta en un control social interiorizado y en la capacidad ilimitada de preguntar a todos los cuerpos. De este modo, el control invisible puede materializarse en la ilusión de la libertad y en escenas de tortura que revelan la siniestra relación entre la verdad y el poder. Mediante el análisis detallado y la lectura minuciosa (close reading) de ciertas escenas clave de la novela, se ofrece una interpretación que explica la dinámica de los personajes y de la novela como una batalla entre la fijación de sentidos desde el poder político y su escritura fosilizada, y la multiplicidad de sentidos de la vida.

Palabras clave: Asturias, El Señor Presidente, historia, cuerpo, poder, pregunta

Orcid ID 0000-0002-5770-8400

https://doi.org/10.18800/lexis.201702.003 


\begin{abstract}
This article discusses the uses of history in the novel El Señor Presidente of Miguel Ángel Asturias and proposes that this is the first Latin American novel that formalizes an elaborate fictional theory of power, which is based on an interiorized social control and on the unlimited capacity of ask all bodies. In this way, the invisible control can materialize in the illusion of freedom and scenes of torture that reveal the sinister relationship between truth and power. Through detailed analysis and close reading of certain key scenes of the novel, an interpretation is offered that explains the dynamics of the characters and the novel as a battle between the fixation of meanings from the political power and its fossilized writing, and the multiplicity of meanings of life.
\end{abstract}

Keywords: Asturias, El Señor Presidente, history, body, power, inquiry

\title{
Introducción
}

Aunque publicada por primera vez en 1946, esta novela fue elaborada principalmente entre 1922 y 1933 . Escrita casi íntegramente en Francia, se nota la influencia del lenguaje surrealista en las asociaciones libres de imágenes, la confusión del sueño y la realidad, la verdad y la mentira como caras de la misma moneda y los creativos juegos verbales; sin embargo, hay un menor experimentalismo en la estructura discursiva. A diferencia de la novela vanguardista típica, plagada de rupturas temporales y espaciales y múltiples perspectivas narrativas que se contraponen, El Señor Presidente $(E S P)^{1}$ posee una estructura en tres partes equilibradas (once, dieciséis y catorce capítulos, respectivamente) y regidas cada una por una segmentación convencional con unidad narrativa y motivo hegemónico en cada capítulo. Sin embargo, se advierte ya el influjo de la crisis de la representación mimética tradicional. Además, como sostiene García-Bedoya (2012), constituye una novela transculturadora, pues enfrenta con armas peculiares el reto modernizador: aliento

\footnotetext{
1 Existen numerosas ediciones críticas, destacan la de Alejandro Lanoëld'Aussenac (1997, 2011) en la editorial Cátedra, y la de Gerald Martin (2000) en la colección Archivos de la Unesco. Nuestras citas pertenecen a esta última edición.
} 
lírico, recreación de la cultura oral-popular y revaloración del aporte indígena.

En la novela, se hallan algunas analepsis y otras formas de ruptura temporal, la trama y la historia no siempre coinciden y hay una concentración temporal en las dos primeras partes de la novela en contraste con la duración indeterminada del tiempo de la tercera parte. Adicionalmente, como ya advirtió Robles (1972), la narración está construida como la suma de múltiples miradas y experiencias regidas por un "montaje de perspectivas contrastantes" que termina construyendo una realidad múltiple y estereoscópica que desafía al lector a reconstruir la unidad del mundo representado (236). Por último, el uso del cine como metáfora de representación de la realidad y la relevancia que adquieren los medios de comunicación masiva como la prensa la sitúan en un diálogo típico de la narrativa vanguardista latinoamericana con las nuevas tecnologías y sus modelos de cognición.

$E S P$ ha sido muy estudiado y se ha destacado su representación descarnada y crítica del poder político omnímodo y la riqueza y flexibilidad del lenguaje. También, se ha reflexionado sobre la apropiación del mito por esta novela y cómo opera el sustrato de las leyendas orales que remiten al dios maya-quiché Tohil en su aspecto destructor y sanguinario, pero no de sus fuerzas vitales y regeneradoras (Rodríguez 1989). Por su parte, en una línea sin continuadores, Jorge J. Barrueto (2004) ha destacado el mimetismo de las élites poscoloniales en códigos positivistas que insuflan al autor y los prejuicios del narrador que enfatizan los aspectos atávicos (primitivismo y degeneración) de los indios. Finalmente, se ha propuesto el modelo de la estructura arquitectónica del panóptico, fundada en el anonimato y la transparencia, como principio estructurador del mundo representado de la novela, que articula a los ciudadanos ubicados en celdas transparentes, pero a la búsqueda de ocupar posiciones de control y vigilancia al interior de la torre del poder (Rojas Pachas 2012).

En este artículo, mediante la lectura minuciosa (close reading) del texto, se busca dilucidar tres problemas asociados con la novela: 
a) las apropiaciones y reconfiguraciones del discurso histórico por la novela; b) el funcionamiento de los mecanismos del control invisible sobre los otros personajes y la sociedad por el Señor Presidente, pináculo del poder; y c) las relaciones entre el papel de la pregunta y del cuerpo en las escenas de tortura, como una teoría de la escritura de la ficción del poder.

\section{Más allá de la novela histórica}

En esta sección, se discutirá si El Señor Presidente constituye una novela histórica, y, si es así, cómo y qué historia representa. Una calificación tradicional defendida por muchos ${ }^{2}$ la denomina "novela vanguardista de carácter político", otros intentan seriarla dentro de la antigua y rica tradición de la novela del dictador ${ }^{3}$ que atraviesa de forma discontinua y con mayores o menores intensidades toda la historia de la novela latinoamericana.

En ESP, nunca aparecen los nombres del dictador Manuel Estrada Cabrera o el de Guatemala ni fecha alguna; por otro lado, la simultaneidad de la vida del escritor con el supuesto periodo histórico representado ha motivado que los críticos descarten su calidad de novela histórica. ${ }^{4}$ Sin embargo, esta novela posee una

\footnotetext{
2 Entre ellos, Gerald Martin que ha dedicado varios estudios a esta novela. Una síntesis de ellos, se puede leer en la Introducción de la edición de la Colección Archivos (2000).

3 El trabajo de Carlos Pacheco, Narrativa de la dictadura y crítica literaria (1987) es un buen ejemplo de ello. Allí se plantea que ESP constituye un hito central no solo en el sistema de la narrativa de la dictadura, sino en toda la narrativa continental (64). 4 Seymour Menton (1993) no la considera novela histórica porque narra eventos que ocurrieron cuando el autor estaba vivo. Por ello, ni siquiera la menciona en su libro. El propio autor traza una diferencia entre los personajes que vivieron y los que están viviendo en el mundo representado y así justifica que la suya no es una novela histórica porque sus personajes pertenecen al segundo grupo (2011: 420). Si asumimos la definición de Magdalena Perkowska "la novela histórica puede concebirse como un espacio discursivo ficcional en el que se articulan lecturas y reescrituras presentes del texto de la historia. Cada novela traza una imagen o visión no solo de un acontecimiento pretérito concreto, sino también de la historia y del discurso histórico y de su relación con el presente" (2008: 37); en esa línea, se puede considerar que ESP reconfigura el discurso histórico y su relación con el presente.
} 
lectura incisiva de los efectos de una forma de poder político históricamente situado sobre toda una sociedad. El centro de la trama consiste en la transformación de un personaje auxiliar del soberano y los efectos de su rebelión. Así, la vida privada de un puñado de personajes se imbrica con la historia pública, ${ }^{5}$ el amor de una pareja desafía al poder absoluto: la ficción asigna sentidos a la Historia y la Historia es materia de la ficción.

Existen muy pocos cronotopos en el mundo representado, el más importante es la mención en el periódico de la batalla de Verdun que coloca el tiempo interno del mundo representado en al año 1916; a pesar de ello, la novela juega magistralmente entre un desanclaje espacial y temporal, y referencias específicas a una historia determinada. Se trata de universalizar la historia deslocalizándola y, simultáneamente, mostrar la universalidad de una historia local. Por otro lado, el sustrato mítico de la novela le asigna mayor densidad al tiempo histórico determinado: nótese que no solo hay referencias al mundo maya-quiché, sino también al mundo bíblico cristiano, como la referencia al ángel caído en la figura de Miguel, él es Lucifer, el ángel que se rebela contra la divinidad.

Esta novela rompe radicalmente con las formas tradicionales de representación de la historia que ponían énfasis en la construcción de la nación y en la tarea, positiva o negativa, en la construcción de sentidos sociales colectivos desempeñada por altos personajes de la vida pública. La novela histórica en el siglo XIX formaba parte del romanticismo y presuponía una visión genealógica del pasado y una gran confianza en el lenguaje como medio idóneo para representar la realidad histórica; de este modo, verosimilitud y verdad histórica se superponían. En ESP no interesa mayormente ni la verdad histórica ni la vida del caudillo, sino la liberación plena de los poderes de la ficción y las posibilidades estéticas del lenguaje para construir un personaje omnímodo arquetípico y una sociedad sometida por

5 La novela histórica según Mijail Bajtin (1991) revela la complejidad de las relaciones entre ficción e historia; el crítico ruso sostiene que en el periodo moderno pretende "encontrar un aspecto histórico a la vida privada, y a su vez, por presentar la historia de manera doméstica” (368). 
el miedo. La unicidad de la estructura del texto literario se orienta a producir en el lector u oyente una nueva visión de la realidad y, simultáneamente, un goce estético que se obtiene de la decodificación del texto. El carácter ficcional se intensifica por el torcimiento constante del lenguaje (sonoridad autónoma del sentido, juegos fonéticos con vocablos y sílabas, asociaciones libres por contigüidad semántica) que colabora decisivamente con la creación de un mundo representado que funciona como una totalidad coherente que produce múltiples significados mediante desplazamientos semánticos.

En síntesis, no estamos ante una novela histórica, pero sí ante apropiaciones de elementos constitutivos de la misma como pasado mítico, personajes históricos, acontecimientos locales y verdad; estos elementos son transformados en conjunción con pares antagónicos (presente histórico, personajes arquetípicos, estructuras universales y mentira) que expresan los límites y la crisis misma del discurso histórico tradicional. En este proceso, de confrontación y simbiosis, se elabora la primera teoría ficcional del poder en la novela latinoamericana.

\section{El poder interiorizado en los súbditos, el cuerpo degradado del amo y las fantasías de la libertad}

La figura del señor presidente posee varios niveles de significación y articula diversas narraciones que atraviesan la novela. Por un lado, representa a un presidente que posee los rasgos típicos del dictador latinoamericano y constituye un orden social donde él posee control absoluto sobre todas las instituciones, existen sistemas múltiples de delación e información que dependen de él, actúan intermediarios que cumplen sus órdenes sin cuestionarlas y se desarrolla un culto hiperbólico a la personalidad. En síntesis, un orden social frágil y subordinado al orden estatal: el cuerpo social regido y sometido por el cuerpo del Señor Presidente. Por otro lado, el presidente remite a la figura del azar supremo con visos de divinidad, él es omnipotente, omnisciente, omnipresente, y tiene control absoluto no solo sobre el presente sino sobre el futuro, es decir, sobre el horizonte de expec- 
tativas y la esperanza de sus súbditos. Sin embargo, hay un elemento azaroso en todo su accionar, algo imprevisible que ratifica su poder. Sus acciones y la motivación de ellas no pueden ser decodificadas plenamente. Además, remite a un hombre que, aunque no aparece muchas veces en el centro de la narración, controla los hilos de todos los personajes (el personaje titiritero que crea una puesta en escena formaliza una representación especular dentro de la representación del poder). Finalmente, cuando el narrador representa directamente al jefe supremo queda configurado como un sujeto insensible, vanidoso y de una refinada crueldad psicológica, ya que gustaba de ofrecer esperanzas a sus víctimas para que su caída fuese más dolorosa. Asturias, en un texto explicativo de su novela, - que hay que tomar con pinzas - lo asocia con el dios maya-quiché Tohily por sus demandas constantes de sacrificio humano (2011: 425).

En esta sección, se estudiará la actuación narrativa y las palabras del Señor Presidente en el capítulo XXXII para identificar de forma precisa en qué radica su poder y cómo lo preserva. En este capítulo, se resuelve la relación entre el Señor Presidente y Cara de Ángel, este último pasa de ayudante próximo al poder supremo a una zona indeterminada que devendrá en su posición de enemigo y víctima. Este desenlace ejemplar constituye un modelo de las relaciones que mantiene el jefe absoluto con su círculo de colaboradores más cercanos y con el resto de la sociedad.

El capítulo XXXII, denominado "El Señor Presidente", se inicia con una disyuntiva de Cara de Ángel entre acudir al llamado del presidente o quedarse a cuidar de su esposa Camila. Esta es la ilusión de la libertad, él cree que elige, pero no tiene opción. Por ello, se dirige a la casa del amo en un carruaje y se distrae contemplando los letreros de la ciudad que se aleja. Él tiene que salir de la ciudad para llegar a la residencia campestre del presidente, dejar la ciudad es abandonar el espacio civilizado; según el imaginario latinoamericano hegemónico en ese tiempo, el campo, en los límites de la ciudad, instaura el espacio de la barbarie. Existe una homología entre la velocidad del coche y los pensamientos vertiginosos de su ocupante, se produce una aceleración que cambia el estado material 
del carruaje "como un cuerpo que pasa del estado sólido al líquido" (2000: 262), mientras que el miedo y la angustia se intensifican también en Cara de Ángel porque no sabe para qué ha sido llamado. Una vez que ingresa a la casa, la ansiedad de saber el porqué del llamado se formaliza en la pregunta al Subsecretario, quien replica: "lo ignórolo" (263), forma verbal que acentúa el desconocimiento absoluto de la lógica de los deseos del amo.

El cuadro que se muestra ante los ojos del visitante, lo explica todo: "un bosque de botellas en una mesa redonda (...) Del fondo de la habitación avanzó el señor Presidente, con la tierra que le andaba bajo los pies y la casa sobre el sombrero" (263). Incluso, en su ebriedad y sin poder vocalizar plenamente las palabras, el que controla el diálogo es él. Existe una broma cruel que anticipa el tema central del capítulo: los vínculos entre el amor y la muerte. Cara de Ángel acaba de casarse en "artículo mortis" con Camila y el Presidente ha perdido uno de sus hombres más leales, asesinado en los Portales. La proximidad de la muerte le ha otorgado al subordinado la posibilidad de acrecentar su existencia privada; la muerte ha privado al amo de un miembro de su cuerpo político.

La broma no advertida en las ediciones críticas de la obra que hemos revisado, ${ }^{6}$ radica en la referencia a "Swit Marden" como un autor que debería conocer el subordinado. Orison Sweet Marden ${ }^{7}$ es un precursor de los libros de autoayuda, un escritor considerado como "espiritista" por su confianza en el poder del pensamiento personal. El Señor Presidente refiere a este autor porque ya sabe que su subordinado se ha casado en "artículo de muerte". Además, puede entenderse que el jefe supremo le imputa a Cara de Ángel

\footnotetext{
6 En la edición de Cátedra no hay ninguna nota y en la monumental edición de Archivos se identifica la referencia al escritor norteamericano, pero no se dice nada en los numerosos estudios sobre la función que cumple dicha alusión en el diálogo de los personajes.

7 Este escritor norteamericano (1850-1924), médico y empresario, obtuvo un éxito fulgurante durante las primeras décadas del siglo XX. Perteneció al New Thought Movement. La importancia del espiritismo para la literatura modernista latinoamericana fue muy significativa, en el caso peruano, los cuentos de Clemente Palma dan cuenta de ello.
} 
dicho conocimiento por la defensa que realiza Marden de la posibilidad que tiene todo hombre de construir su futuro, recuérdese que el auxiliar se ha casado sin consentimiento del amo. El subordinado no percibe la doble broma.

Este primer intercambio establece ya una jerarquía entre ambos interlocutores remarcada explícitamente por el subordinado: divididos por la posesión de un saber absoluto por un lado y la ignorancia plena por el otro. Desde esta fractura, adquiere un nuevo sentido la palabra "Minerva" que el ebrio no pudo pronunciar. La diosa del conocimiento está asociada al poder porque el poder crea un régimen de verdad que constituye el sentido de la práctica social de todos los subordinados. Además, Minerva encarna la hegemonía de los valores de la guerra y del poderío militar, atributos de la sociedad representada en la novela. Las referencias a las figuras de la mitología romana son frecuentes entre los dictadores latinoamericanos creados por la literatura, muchos de los cuales poseen un profundo conocimiento del mundo greco-latino y de las bases culturales de la civilización occidental como en el caso de Yo el supremo de Roa Bastos. La alianza entre la escritura y el poder adquiere allí su verdadera dimensión.

El ebrio que no puede hablar recibe ayuda del sobrio para que el primero prosiga con la burla de su matrimonio. El ejercicio del poder absoluto solo es posible porque los subordinados colaboran activamente en esa maquinaria, ellos han interiorizado que la desaparición del jefe supremo constituye el final del sentido social. La risa entrecorta las palabras del Señor Presidente, pero repite constantemente la frase "en artículo de muerte" para remarcar el acto ridículo de su subordinado motivado por "consejo de un débil mental como todos los espiritistas" (264). Ante esto, ¿cuál es la respuesta del burlado y humillado? Se doblega ante el poder/saber absoluto: "Seguía siendo el perro educado, intelectual, contento de su ración de mugre, del instinto que le conservaba la vida. Sonrió para disimular su encono" (264). Por un momento, reaparece la ilusión de la libertad y piensa en golpear al que lo denigra, "acababa de estar a punto de lanzarse sobre su amo y apagarle en la boca la carcajada miserable" (264); 
sin embargo, no lo hará porque no cabe la rebelión abierta entre los súbditos que han interiorizado la Ley del amo.

Abruptamente, la conversación toma otro rumbo porque el presidente empieza a perseguir infructuosamente a una mosca: “Miguel, ¿tú no conoces el juego de la mosca...?” (264). El jefe sentencia que es un juego divertido, fácil de aprender y donde solo se requiere paciencia. La alegoría es evidente, todos sus súbditos, incluyendo Miguel, son pequeños insectos que él puede atrapar y destruir cuando le plazca porque todos vuelan en órbitas que giran alrededor de la propia figura del Señor Presidente.

Posteriormente, el presidente recuerda que en su pueblo durante su infancia se entretenía con el juego de la mosca. Este recuerdo es ingrato y, por ello, descarga un puñetazo sobre el nombre de su pueblo en el mapa que cuelga de una pared. Aquí, el poderoso personaje inicia una visión retrospectiva y brinda algunos puntos clave en su recorrido vital: el niño pobre, el joven que trabajaba y estudiaba, el abogado con casos de poca monta. Queda claro que el gobernante viene del pueblo y de orígenes sociales humildes y se debe inferir que alcanzó el poder por sus méritos propios y no por sus alianzas con las élites económicas. El narrador parece sugerir cierta ética del resentimiento, el hoy omnímodo personaje no soporta recordar las humillaciones que sufrió en ese pueblo en el pasado. El letrado mestizo de "tercera clase" que ascendió a lo más alto no perdona a los que lo ofendieron cuando era vulnerable. Por otra parte, en ese breve viaje verbal al pasado no hay referencia al padre, remisión a otra estructura típica del mundo sociocultural latinoamericano: el padre ausente. Por ello, se genera inmediatamente la asociación con Parrales, quien fue la persona que lo vengó ya que "potreó a mis paisanos, porque los puso en cintura (...) y de no ser mi madre acaba con todos para vengarme de lo mucho que tengo que sentirles y que sólo yo sé...” (265-266). Hay un dolor traumático, una falta que no ha podido ser suplida plenamente, una carencia de reconocimiento que duele y que puede ser una de las claves de la actuación del jefe supremo: la violencia del poder absoluto contra los súbditos como una forma de llenar ese vacío interior, de ser, finalmente, reconocido por el padre invisible y por los otros. 
Aunque Asturias evita describir en detalle el rostro de El Señor Presidente, sus orígenes sociales, la asociación con Tohil y la adjetivación "rostro de jade" lo colocan en un mundo social permeado por lo indígena. Cabe recordar que muchas de las grandes figuras literarias e históricas del dictador latinoamericano asumen la forma de personajes mestizos con herencia africana o india que llegan al poder bajo la forma de caudillos militares. Por ejemplo, en el texto El gran Burundún-Burundá ba muerto (Zalamea 1968), más allá del título con indudables ecos africanos, hay una racialización del tirano mediante una adjetivación despectiva de sus rasgos afrodescendientes: "patizambo, corto de muslos, de torso gorilesco, cuello corto, voluminosa cabeza y chocante rostro (...) El breve ensortijado del cabello y la prominencia de los morros, le daban cierto cariz negroide" (29). En Yo el Supremo (YES), la herencia africana es inaceptable y dolorosa para el dictador en la escena en la que su criado negro viste su uniforme de gala: “iLo peor es que en la alucinación de mi cólera me veo retratado de cuerpo entero en ese esmirriado negro!" (Roa Bastos 1983: 548). ${ }^{9}$ Por otro lado, en la misma novela de Roa Bastos, la reivindicación de la herencia guaraní, la media hermana bruja y uno de los nombres que se asigna, Karaí-Guasú, remiten a un sujeto que se alimenta del sustrato indio guaraní. Tanto en ESP como en $Y E S$ se manifiesta la voluntad de la figura del dictador de apropiarse del sustrato mítico indígena para darle un mayor simbolismo y legitimidad a su gobierno. Entre las dos novelas, hay otras semejanzas e intertextualidades ${ }^{10}$ que no estudiaremos aquí.

En todo el diálogo con el favorito, el Señor Presidente va sufriendo un proceso de degradación física: "recobró el habla a

\footnotetext{
8 Esto se puede considerar una referencia a las célebres máscaras de jade del mundo maya.

9 Para revisar los mecanismos de la construcción discursiva del esclavo y del afrodescendiente en la literatura, puede consultarse el primer capítulo de mi libro Las máscaras de la representación (2004).

10 Mencionamos algunas de las más visibles: los dos auxiliares, Cara de Ángel y Patiño, son muertos por el jefe supremo acusados de traición; el traslado de las mujeres de las prisiones a la Casa de Muchachas Huérfanas y Recogidas en YES (486) parece inspirado en el episodio de Niña Fedina; la resistencia de El Mosco ante la tortura se repite en la resistencia del criado negro (550) en YES.
} 
pequeños eructos” (264), "la falda de la camisa al aire, la bragueta abierta, los zapatos sin abrochar, la boca untada de babas y los ojos de excrecencias color de yema de huevo" (265). Este cuerpo va, gradualmente, vaciando sus interioridades (eructos, babas) y mostrando el cuerpo desnudo. La escena culminante de este proceso se produce cuando el presidente, reclinado sobre el favorito, "no tardó en soltar un chorro de caldo anaranjado” (266). Aquí se completa la imagen degradada del dictador que no solo vomita, sino llora lastimosamente por el Coronel asesinado. Las secreciones del cuerpo del dictador fluyen incontenibles. Por otra parte, la imagen grotesca del vómito sobre la palangana que tiene esmaltado el escudo de la república en el fondo es harto elocuente. Sin embargo, más allá del obvio sentido del desprecio por los símbolos patrios hay otro relevante: sus palabras se convierten en una sustancia que cubre metonímicamente toda la república. Sus palabras transmutan, de allí este símil previo: "las palabras tonteaban en sus labios como vehículos en piso resbaloso" (266). Sus palabras se convierten así en el líquido viscoso anaranjado que cae sobre el auxiliar y sobre la nación. Incluso en su degradación física conserva su poder sobre toda la comunidad política. Sin embargo, ha sido esta degradación producida por el alcohol la que ha permitido conocer parte de su vida privada pasada: el cuerpo físicamente vulnerable deviene en psicológicamente más débil.

En este capítulo, la embriaguez del gran jefe está narrada con gran realismo no solo en el proceso mismo de pérdida de los sentidos, sino sobre todo en su discurso entrecortado, divagatorio, pero repetitivo en ciertos significantes claves. Se desliza semánticamente por contigüidad entre las burlas al matrimonio de Cara de Ángel, al juego de la mosca, a su infancia desdichada, a la muerte del coronel Parrales y, finalmente, al lamento por la ingratitud de los súbditos insumisos ¿Existe alguna trayectoria de sentidos en estos deslizamientos del discurso del ebrio? A primera vista, parece difícil encontrar la ilación. Planteamos dos desplazamientos diferentes:

(A) En el orden emocional-subjetivo, el personaje del Señor Presidente se mueve de la autosuficiencia con la que se burla del otro, 
formalizada en la risa, al despecho que se materializa en el llanto. La transición está dada por el gran dolor que se desprende de la evocación de su infancia y juventud, que se formaliza en rabia.

\section{Tabla 1}

\begin{tabular}{|l|c|c|c|}
\hline Estado emocional & Autosufiencia & Dolor & Despecho \\
\hline Manifestación material & Risa & Rabia & Llanto \\
\hline
\end{tabular}

Podemos concluir que en esta dimensión el sujeto se desplaza desde la satisfacción egolátrica hasta la insatisfacción por la pérdida del objeto de deseo (el amor de todo su pueblo) porque ya hay elementos que conspiran contra él, como lo prueba la muerte de Parrales.

(B) En el orden espacial/temporal, el personaje ebrio también sufre desplazamientos. Aunque toda la escena se realiza en las habitaciones de la casa campestre presidencial, los movimientos del amo sufren transformaciones. Sus movimientos se intensifican y luego decrecen hasta la inmovilidad: se dirige hacia su interlocutor, persigue una mosca, golpea el mapa, finalmente, es sostenido por Cara de Ángel (no-movimiento). Temporalmente, su discurso se refiere al pasado inmediato (el matrimonio de su auxiliar), al pasado más remoto (su infancia y juventud) y, de allí, retorna al pasado próximo (muerte de Parrales). En los dos ejes, hay un periodo climático, pero el final es la ausencia de movimiento o la ausencia de tiempo figurativizada en la muerte (no devenir) de Parrales.

\section{Tabla 2}

\begin{tabular}{|c|c|c|c|}
\hline $\begin{array}{c}\text { Movimiento } \\
\text { personaje }\end{array}$ & Movimiento & $\begin{array}{c}\text { Movimiento } \\
\text { Intenso }\end{array}$ & No-movimiento \\
\hline Tiempo referido & Pasado inmediato & Pasado remoto & Pasado próximo \\
\hline Evento central & $\begin{array}{c}\text { Matrimonio de } \\
\text { C. A. }\end{array}$ & $\begin{array}{c}\text { Infancia/juventud } \\
\text { S. P. }\end{array}$ & $\begin{array}{c}\text { Muerte de } \\
\text { Parrales }\end{array}$ \\
\hline
\end{tabular}


El discurso de El Señor Presidente se enuncia desde diversos estados emocionales acompañados de manifestaciones materiales y movimientos diferenciados del personaje. Se refiere a acontecimientos situados a diversa distancia en el pasado, pero todos poseen ya un significado que no se puede discutir. Se produce una fijación del sentido del pasado que solo él controla y que terminará imponiendo a sus súbditos. El "diálogo" que mantiene con su auxiliar no es tal porque no hay significados sociales comunes que se construyan mediante el intercambio de palabras. La ebriedad del jefe y la degradación de su cuerpo no implican en ningún momento pérdida del control absoluto sobre todos, representados metonímicamente por Miguel. Además, se constituye la fantasía de la libertad entre los súbditos, ellos creen actuar libremente, pero sus acciones tendrán siempre el significado que el amo imponga porque han interiorizado el dominio que padecen. Finalmente, la importancia de Parrales no parece provenir solo del cariño al auxiliar incondicional, sino de la función que desempeña en la estructura psíquica del jefe. Parrales es el padre que castiga a los que se burlaron del hijo desvalido, él encarna la Ley de la venganza y, por ello, su muerte debe quedar cruelmente vengada. Cara de Ángel y su flamante esposa quedan así configurados como traidores potenciales y, en consecuencia, cómplices de los “asesinos" de Parrales.

Una vez que el presidente sale de escena, Cara de Ángel, gracias al Subsecretario, comprende todo el horror de la reunión. Él se ha casado sin autorización del amo creyendo ejercer su libertad. Esta ilusión es destruida violentamente, el amo ha incorporado su acto de libertad en un acto de gobierno y mediante una nota periodística falsa le ha cambiado completamente el signo: la rebelión se ha convertido en sumisión y la libertad en esclavitud. Por ello, Camila, "El único ser que le era querido bailaba [,] ya en la farsa en la que bailan todos" (267). El Señor Presidente se ha instituido como padrino del enlace, y los parientes que le negaron apoyo a su esposa aparecen liderando la lista de amigos que celebra la unión matrimonial. La modesta y precipitada ceremonia se ha transfigurado en un evento festivo realizado en la propia casa del presidente. La escritura del 
papel periódico ${ }^{11}$ no solo ha distorsionado completamente la realidad, sino que ha inscrito el acto disidente en realidad oficial. Se asiste a la victoria de la alianza del poder político con los medios de comunicación masiva sobre la libertad y la singularidad del individuo.

Durante su regreso a casa, el auxiliar pasa por distintos estados emocionales: rabia, llanto, impotencia y sueños de venganza. Tiene una alucinación en la que contempla el cadáver del tirano, pero esa fantasía es inadmisible y le provoca miedo y esconde el rostro en el carruaje "temeroso de que el cochero adivinará lo que veían sus ojos" (268). Revelador pasaje que demuestra cuán interiorizado está en los súbditos el poder, ya que no se permiten plenamente ni siquiera la fantasía compensadora. Cara de Ángel tiene el traje manchado del vómito recibido, pero lo que se hace insoportable es la burla recibida: "iSi pudiera limpiarme la carcajada que me vomitó en el alma!” (268).

El análisis de este capítulo ilumina en varios aspectos la estructura del poder que posee el Señor Presidente, paradójicamente, el estado liminal del amo muestra mejor los resortes de su dominio. El suyo es un poder que se basa en la posibilidad de fijar los significados de los acontecimientos a su libre albedrío y que cuenta con la complicidad de los sometidos que prefieren vivir la ilusión de libertad girando como moscas alrededor del cuerpo del amo. Este cuerpo puede degradarse y hacerse vulnerable, pero nunca pierde el control sobre las acciones y, quizá más importante, las expectativas y esperanzas de sus súbditos. Por otro lado, Cara de Ángel sella su destino, su lealtad se ha quebrado definitivamente e iniciará una rebelión solapada contra el poder que se manifiesta cabalmente cuando desobedece, capítulos más adelante, una orden directa de El Señor Presidente: ${ }^{12}$

11 El papel de la prensa como prolongación del poder del dictador remite un tópico de larga data. La singularidad en ESP radica en el poder mortal que porta la noticia distorsionada. El general, padre de Camila, morirá al leer la falsa noticia de la fiesta de su boda; al final de la novela, el propio Cara de Ángel morirá al leer en el periódico que su amada se ha convertido en amante del tirano.

${ }_{12}$ En el capítulo XXXV, en una fiesta que ofrece el jefe supremo, él ordena que todos los varones se retiren pues quiere cenar solo con las damas, pero Cara de 
el amor a su esposa puede más que el miedo al amo, pero eso solo confirmará su muerte final y la destrucción de su matrimonio y de la confianza de su esposa. El jefe supremo no soporta que uno de los miembros de su cuerpo político ame más a una mujer que al poder encarnado en el cuerpo del presidente; por ello, el amor de Cara de Ángel lo conducirá indefectiblemente no solo a la muerte, sino a una desintegración material (disentería aguda).

3. Tortura y pregunta: la escena de la ficción del poder

Elaine Scarry (1987) ha establecido que la tortura consiste en un acto físico primario: infligir dolor; este va siempre acompañado de un acto verbal primario, la interrogación. Desde esta perspectiva, el proceso de la tortura remite a la ficción del poder porque escenifica una acción simbólica que pretende el control absoluto sobre el cuerpo, la voluntad y los pensamientos de la víctima (28 y ss.). En este apartado, se analizará el mundo representado y los procedimientos discursivos en dos escenas de tortura en la novela de Asturias (cap. II y cap. XVI). Nuestras variables son poder, cuerpo y pregunta.

En el segundo capítulo, se interroga a unos mendigos detenidos que han contemplado la muerte del coronel Eugenio Parrales. Primero, pasaron al calabozo, luego, a la oficina del Auditor y finalmente, al cuarto de torturas. Este desplazamiento intensifica la angustia que desemboca en la mirada del instrumento, la cuerda para ser colgados de los pulgares en el aire. Inicialmente, el primer torturado declara la verdad, es decir, que El Pelele mató al coronel. Cree ilusamente que la verdad lo salvará y así podrá evitar el dolor. Sin embargo, la voz del Auditor se impone exclamando lo siguiente: "Yo le voy a decir, a ver si se atreve a negarlo, quiénes asesinaron al coronel Eugenio Parrales Sonriente; yo se lo voy a decir...jEl general Eusebio Canales y el licenciado Carvajal!” (19). Entonces,

Ángel no obedece y se queda oculto detrás del cortinaje para proteger a su esposa. Este es su acto de rebeldía expreso y público. 
el primer torturado y todos los mendigos se pliegan y repiten las palabras del Auditor. Como se dice en la Circular perpetua de Yo El Supremo: "El Aposento de la Verdad hace milagros" (395). Allí, en el cuarto de la tortura, el poder no solo modela los cuerpos, sino también la experiencia de realidad, pues se fusiona la pregunta con la verdad oficial.

Entre todos los mendigos, hay uno que se niega a defender esa mentira. El Mosco, un ciego que carecía de las dos piernas, se mantiene firme enarbolando la verdad. Por ello, es torturado físicamente: colgado y golpeado con un látigo en el rostro. Pese a esto, se niega a cambiar su versión y, finalmente, muere: "el cadáver de El Mosco, es decir, el tórax, porque le faltaban las dos piernas, cayó a plomo como péndulo roto" (20). La significación de esta escena acentúa el dramatismo de la tortura, ya que el hombre que no puede ver es el único que defiende la verdad y el hombre mutilado es el más íntegro moralmente. El tormento logra que el torturado conteste la pregunta con las palabras del poder o arranca la voz del cuerpo de la víctima, como en este caso; en consecuencia, las últimas palabras de El Mosco quedan violentamente cortadas. Los mendigos que mintieron por miedo y aceptaron públicamente la verdad oficial sobreviven; el que se atrevió a cuestionarla muere inexorablemente: el símil empleado acentúa el dramatismo y la cosificación que le imponen el poder. Su apelativo de El Mosco adquiere visos de humor negro cuando lo imaginamos colgado y oscilando en el aire, el suyo es un falso vuelo, ya que está sometido al vaivén de la cuerda que alegoriza el control del poder. Con esta escena de tortura, se funda la ficción del poder, la lógica de preguntas que ya tienen respuesta de antemano, la verdad oficial que se impone sobre la experiencia de los sentidos. Por último, esta microescena es un anticipo de lo que le ocurrirá a Cara de Ángel, cuando se atreva a enfrentarse al poder y expresa resonancias semánticas entre el apelativo de El Mosco y el juego de las moscas.

En el capítulo XVI, titulado "En la casa nueva", se representa una de las escenas de tortura más violentas y significativas de toda la novela. A diferencia del caso anterior, donde los interrogados 
conocían lo ocurrido realmente, pero su verdad era irrelevante para el poder; aquí tenemos a una mujer que no sabe lo ocurrido, pero su ausencia de saber es inadmisible para el poder. En el capítulo, se representan tres escenarios simultáneos: a) la prisión, interrogatorio y tortura de Niña Fedina; b) el patio de la prisión donde las reclusas cantan una tonada una y otra vez; c) las calles de la ciudad que celebran una fiesta en honor del Presidente.

Si el lenguaje es la morada del hombre, el título del capítulo alude a un nuevo hogar en el cual las formas y usos del lenguaje convencional se van a transformar violentamente. Además, claro se hace alusión a la cárcel en que se halla Niña Fedina. Antes de la reclusión, sus captores realizan dos actividades complementarias: a) establecen su ubicación en el orden social mediante la identificación precisa de su nombre, edad y generales de ley, es decir, ellos le asignan un espacio/tiempo singular, pero sometido al mapa estatal; b) registran su cuerpo, "de la cabeza a los pies, de las uñas a los sobacos" (128), es decir, establecen que su cuerpo es un territorio donde ellos pueden ejercer su escrutinio.

El calabozo es muy estrecho y, si se sienta, el frío del piso helado penetra en su cuerpo. La celda no solo la priva de la libertad física, sino que comienza el proceso de revelarle que el suyo, como el de todos, es un cuerpo frágil sobre el cual Niña Fedina empieza a perder el control; por ello, "y a levantarse, y a sentarse, y a levantarse...” (128). Posteriormente, ella escucha una canción de las otras presas que están en el patio, canción que expresa el anhelo de pasar de la cárcel a una casa de prostitutas (esto funciona como una anticipación de lo que le pasará a Fedina), pero en ese momento le hiere la crudeza del texto y la "verdad atormentadora" que porta: su cuerpo vuelve a temblar, pero ya no de frío sino de miedo.

El recuerdo de su hijo crea una barrera que la protege, se abstrae de su nuevo entorno y disfruta mediante la memoria y las proyecciones del bautizo inminente. El personaje todavía actúa mentalmente como una persona con pasado y expectativas; sin embargo, esto dura poco. Los dibujos groseros y grotescos que pueblan las paredes de la celda la devuelven a su nueva realidad y 
cuando baja la mirada al suelo observa que "un pueblo de hormigas se llevaba una cucaracha muerta” (131). Allí tiene una visión sexual. Las relaciones entre prisión y sexualidad son complejas, no se trata solo del deseo contenido, sino de hallar en el encuentro sexual la libertad del cuerpo propio, pero sobre todo el reconocimiento del mismo por otro.

La fiesta en honor al presidente se expresa alegóricamente en el desplazamiento de la gente de bien alrededor de la plaza, una y otra vez dan la vuelta, ofreciendo un espectáculo adicional al pueblo que observa también un espectáculo de proyección de imágenes. La plaza funciona como un espacio vacío que representa el significante del poder, el cuerpo ausente del presidente, alrededor del cual todos giran como satélites. Además, esto refuerza el carácter de prisioneros de todos, de los recluidos y de los que pasean por la ciudad: el sentido y el poder del Estado representados en la figura del señor presidente dominan la totalidad social. La proyección de imágenes en la "manta de las vistas" parece sugerir que las nuevas tecnologías de comunicación aparecen contiguas a las formas del poder, como dice el texto explícitamente: "reemplazan al patíbulo" (131). ${ }^{13}$ Una representación de imágenes fijas que termina fijando la imagen de los ciudadanos en códigos de una representación inmóvil dentro de la representación narrativa. Adicionalmente, se puede considerar el carácter fantasmagórico de esas vistas que alegorizan la fantasmagoría del poder que no se ve, pero está actuando sobre todos.

Después del refugio en la memoria personal, la mujer encarcelada busca consuelo en la oración religiosa, en la fe colectiva. Ella inicia una larga oración que concluye en la letanía ora pro nobis que se repite varias veces. La repetición constituye una marca del ejercicio del poder que siempre es el mismo, no puede dejarse de mencionar que, aunque ella ora a la divinidad, también está pidiendo simultáneamente, quizá sin saberlo, al señor presidente que interceda por ella.

\footnotetext{
13 El patíbulo remite a la picota o rollo colonial, esta expresión del poder punitivo de la autoridad real es el lugar del castigo público, el espacio donde la ley se convierte en un espectáculo que puede ser disfrutado por la comunidad.
} 
A lo largo de la novela, el sonido de las campanas alude a una presencia inmaterial que cubre toda la ciudad y así remite inequívocamente al poder del dictador. Por ello, después de escuchar las doce campanadas se inicia el interrogatorio. Después de contestar sus generales de ley, la acusada hace una pregunta que no se representa directamente en el texto porque el narrador arguye que "no se oyó bien porque a tiempo llamaron por teléfono" (133). La respuesta a la pregunta ausente, además de irónica, expresa la lógica del poder: "pues no tenga cuidado, que para eso estamos nosotros aquí, para dar informes a las que, como usted, no sabe por qué están detenidas..." (134). Aquí se establece una curiosa dialéctica entre las preguntas de la víctima y la pregunta de sus torturadores; las preguntas de ella buscan comprender el sentido de su prisión, buscan la coherencia de su experiencia en el mundo; en contraste, la pregunta de ellos es el motivo de su prisión y busca aniquilar toda su experiencia sensorial, ya que ella se ha convertido solamente en un cuerpo que porta una respuesta relevante para el poder. Por ello, en tanto las preguntas de la víctima buscan reconstituir su subjetividad, la pregunta del poder la objetiva y cosifica plenamente.

Se interroga a Niña Fedina sobre el lugar donde se halla el general Canales. La pregunta se repite una y otra vez de forma obsesiva. Las respuestas negativas de la interrogada no cuentan, ella repite que no vio ni cruzó palabra con el general. " $\mathrm{La}$ autoridad lo sabe todo, y sabe que usted habló con el general” (135), le increpa el Auditor. La escena del interrogatorio tiene como telón de fondo al amanuense que copia las respuestas de la interrogada, este se configura como un sujeto poseedor de un saber decir y saber escribir; por ello, descalifica el uso de una expresión popular de la interrogada mediante la expresión: "Ni hablar sabe" (135). En otra referencia a los principios de la cultura colonial latinoamericana: la escritura debe formalizar la voz, la declaración oral queda sometida al papel para tener valor legal.

Ante las reiteradas negativas de la interrogada, se la amenaza con la muerte de su hijo. Se abre una puerta para que ella escuche el llanto de hambre de su bebé. Ella lucha contra los guardias, suplica, 
se arrodilla, pero todo es inútil. Incluso pierde parte de la ropa en estos intentos y muestra su cuerpo desnudo como un proceso de deshumanización inevitable. Sin embargo, todo es inútil, la pregunta vuelve a imponerse: “¿Dónde está el general?”. “Niña Fedina callaba como una bestia herida, mordiéndose los labios sin saber qué hacer" (138). Finalmente, es golpeada duramente y obligada a moler cal durante horas, la pregunta se sigue repitiendo cada cierto tiempo. Casi al amanecer, es devuelta al calabozo y se le entrega su bebé casi moribundo. Este intenta lactar, pero la leche de ella está contaminada por la cal y el bebé la rechaza y muere a los pocos minutos de hambre y de frío.

¿Cómo interpretar esta escena? El poder no ha podido obtener la respuesta que desea, la víctima doblegada no podía contestar dicha pregunta porque desconocía su respuesta. La mujer popular, inocente e ingenua, se ha transformado dramáticamente. En pocas horas, la tortura ha logrado que ella se perciba como culpable ya que su no-saber ha sido la causa de la muerte de su hijo. Mediante un sofisticado y terrible ejercicio de violencia semiótica, la leche materna ha quedado sustituida por la cal, ambas son de color blanco grisáceo y brillo opaco, pero en la narración el líquido nutriente queda convertido en una especie de veneno. Quizá, para ser más precisos, podríamos decir que la cal la separa para siempre de su mundo, ella ha quedado disociada para siempre de su hijo recién nacido, es decir, ha perdido su futuro. Hay una refinada crueldad que crea una analogía: la mujer no puede salvar a su hijo porque no puede colaborar con el poder. El poder aparece como la gran ubre que alimenta a todos, pero que castiga ferozmente a los que no corresponden a sus desvelos. Finalmente, el sujeto que ha quedado destetado para siempre no es solo el bebé, sino también la madre, su locura y muerte próxima solo confirman esta situación.

A lo largo de todo el capítulo hay una serie de alusiones al campo semántico de la succión, y al espacio de la boca y los labios que anticipan y dan mayor consistencia a la escena capital. Se presentan las distintas modulaciones verbales de la víctima: esperanza, burla, sinceridad, súplica, impotencia, desconsuelo; la pregunta machacando 
el tiempo/espacio una y otra vez; ella queriendo besar los zapatos del Auditor, mordiéndose los labios; la baba de cal que le chorrea de los labios a la madre y el llanto del niño que se va convirtiendo en gemido, en sonido inarticulado. Paralelamente, algunas imágenes, como "Al que le tiemblan las mandíbulas sin poder hablar está telegrafiando angustias" (137) o "El amanuense se chupaba las muelas" (138), se inscriben en el mismo campo semántico. Estos procedimientos discursivos intensifican la relación entre los significados de hablar y succionar: una palabra suya bastará para salvarla, pero ella no puede ofrecerla.

Al final de la escena, ya con el hijo moribundo en brazos, golpea la puerta y grita desesperada que le abran por Dios. Después deja los enunciados apelativos y solo clama invocando a sus santos mediante enunciados expresivos. La mujer no puede aceptar la realidad, ni los hombres ni las divinidades la escucharán. Su hijo, ese suplemento de su cuerpo, ese cadáver vacío de vida le recuerda dramáticamente que ella no pudo ofrecer el significado que el poder requería. Por lo tanto, ella, ayer madre y fuente de vida, hoy es ya un cuerpo vacío, un significante estéril.

\section{Reflexión final}

El Señor Presidente es una novela moderna, con un lenguaje lleno de pliegues, torceduras y deslices semánticos, que emplea y desestabiliza los elementos de la novela histórica. De este modo, combina cabalmente estética y política en la creación de un mundo esperpéntico e hiperbólico, pero de una verosimilitud perturbadora para el lector por la teoría ficcional del poder que presenta.

En la sociedad representada, el cuerpo político de la comunidad y el cuerpo físico del jefe supremo se superponen. Él posee control absoluto sobre sus súbditos y sus esperanzas mediante la concesión de la ilusión de la libertad. Aunque el cuerpo físico del Señor Presidente pueda estar degradado temporalmente, conserva su dominio, pues todos los miembros de la sociedad han interiorizado su control. Ese dominio total se materializa en las palabras que puedan 
transmutarse en otra cosa, pero que crean regímenes de verdad que fijan los sentidos de los acontecimientos del pasado, del presente y del futuro.

La escena de la tortura se convierte en el punto ciego de esta maquinaria, donde el poder alcanza paradójicamente su más alta expresión y sus límites. Entre los procedimientos discursivos destaca la singularización de la víctima, en contraposición a la despersonalización que caracteriza a los personajes que operan el mecanismo de la tortura. El cuerpo de las víctimas, el último reducto de sí mismas, queda recluido en el cuarto de la tortura para confrontarse con la verdad del poder, sus resistencias o derrotas no modifican la lógica inquisitiva que puede registrarlas, afectarlas y matarlas. Sin embargo, la escritura también ingresa a dicho cuarto, ya que es la contraparte del poder y necesita formalizar la voz, la respuesta del cuerpo torturado para que esta tenga valor legal y se convierta en documento de la historia.

La palabra del poder se expresa siempre a través de la pregunta. Esta pregunta puede ser un simulacro, ya que normalmente el poder posee una respuesta de antemano y esa es la única que aceptará del cuerpo torturado. Cuando la pregunta busca nueva información, el cuerpo interrogado no tiene escapatoria, si no conoce la respuesta, se convertirá en un cuerpo violentado, en un significante vacío para siempre.

La fijación arbitraria de significados por parte del poder de todas las acciones de sus subordinados remite a un lenguaje fosilizado que solo opera verticalmente y es enemigo del diálogo y la construcción conjunta de sentidos comunes. En contraste, los juegos verbales del narrador para constituir la experiencia de realidad de sus personajes demuestran las formas de resistencia lingüísticas/políticas de la propia novela. Por otro lado, la relevancia y deformación del sentido de la pregunta tiene en la base una teoría de la escritura como mera proyección o suplemento de la lógica del poder, una escritura que emana del acto de tortura como documento oficial y que, nuevamente, es desafiada por las múltiples perspectivas, sensibilidades y lugares de enunciación, es decir, por la vida y las voces de los propios personajes. 


\section{Referencias bibliográficas}

Asturias, Miguel Ángel

[1946] 2000 El Señor Presidente. Edición crítica. Coord., Gerald Martin. Barcelona/Madrid: ALLCA/Colección Archivos.

[1946] 2011 El Señor Presidente. 1997. Ed., Alejandro Lanoël-d'Aussenac. Madrid: Cátedra.

2011 "El Señor Presidente como mito”. El Señor Presidente. Madrid: Cátedra, 417-428.

BAJTIN, Mijail

[1975] 1991 Teoría y estética de la novela. Madrid: Taurus.

BARRUETO, Jorge J.

2004 "A Latin American Indian Re-reads The Canon. Postcolonial Mimicrity in El Señor Presidente". Hispanic Review. Summer 2014, 339-356.

García-Bedoya M., Carlos

2016 "Miguel Ángel Asturias y la nueva narrativa hispanoamericana”. En Indagaciones heterogéneas. Estudios sobre literatura y cultura. Lima: Universidad Nacional Mayor de San Marcos, Pakarina Editores y CELACP, 95-104.

Menton, Seymour

1993 La nueva novela histórica de la América Latina. México: FCE.

Pacheco, Carlos

1987 Narrativa de la dictadura y crítica literaria. Caracas: Ediciones CELARG.

Perkowska, Magdalena

2008 Historias híbridas. La nueva novela bistórica latinoamericana ante las teorías posmodernas de la historia. Madrid - Vervuert: Iberoamericana.

Roa Bastos, Augusto

1983 Yo el Supremo. Edición de Milagros Ezquerro. Madrid: Cátedra.

Robles, Humberto

1972 "Perspectivismo, yuxtaposición y contraste en El señor Presidente". Revista Iberoamericana. XXXVIII, 79, 215-236. 
RODRÍGUEz, Teresita

1989 La problemática de la identidad en El Señor Presidente. Amsterdam/Atlanta: Ediciones Rodopi B. V.

Rojas Pachas, Daniel

2012 "El panóptico como modelo de poder en la novela El Señor Presidente de Miguel Ángel Asturias”. Revista de Filosofía. 68, 155-165. https://doi.org/10.4067/s0718-43602012000100011

SCARRY, Eliane

1985 The Body in Pain. The Making and Unmaking of the World. Oxford: Oxford University Press.

Velázquez Castro, Marcel

2005 Las máscaras de la representación. El sujeto esclavista y las rutas del racismo en el Perú (1775-1895). Lima: Fondo Editorial de la Universidad Nacional Mayor de San Marcos - Banco Central de Reserva del Perú.

Zalamea, Jorge

1968 El gran Burundún-Burundá ha muerto. Cuba: Casa de las Américas.

Recibido: 15/06/2017

Aceptado: 24/10/2017 